\title{
INDUKSI TUNAS SENGON (Falcataria moluccana) BEBAS KARAT PURU SECARA IN VITRO UNTUK MENDUKUNG PEMBANGUNAN HUTAN RAKYAT SECARA BERKELANJUTAN
}

\author{
Novi Syatria $^{1)}$, Hery Suhartoyo ${ }^{2)}$, Enggar Apriyanto ${ }^{2)}$ \\ 1) Mahasiswa Program Pascasarjana Pengelolaan Sumberdaya Alam UNIB \\ ${ }^{2)}$ Jurusan Kehutanan Fakultas Pertanian Universitas Bengkulu
}

\begin{abstract}
ABSTRAK
Salah satu jenis yang direkomendasikan untuk industri kayu adalah Falcataria moluccana (sengon). Saat ini pertanaman sengon banyak diserang oleh penyakit karat puru. Penyakit ini menyebabkan daun mengeriting, melengkung, tidak normal dan menyebabkan kematian tanaman. Salah satu solusi mengatasi penyakit karat puru adalah mengembangkan bibit sengon yang bebas karat puru secara in vitro. Tujuan penelitian ini untuk mengetahui pengaruh pemberian zat pengatur tumbuh Benzyl Amino Purine BAP) dan Naphtalene Acetic Acid (NAA) terhadap pertumbuhan eksplan tunas sengon, dan mencari media terbaik untuk memacu pertumbuhan eksplan sengon. Penelitian menggunakan media MS dengan perlakuan BAP pada dosis $0,1,2$, dan $3 \mathrm{ppm}$. Konsentrasi NAA sebesar 0, 0.25, dan 0,5 ppm. Total ada 4 × $3=12$ kombinasi perlakuan dengan 5 ulangan. Setiap ulangan terdiri atas 1 eksplan. Peubah yang diukur dalam penelitian ini adalah persentase tumbuh eksplan dan jumlah tunas yang terbentuk per eksplan. Peubah tambahan seperti eksplan yang berkalus dan warna kalus. Pengukuran dilakukan setiap dua minggu selama tiga bulan. Data dianalisis varian kemudian diuji lanjut DMRT pada taraf 5\% dan 1\%. Hasil penelitian menunjukkan bahwa perlakuan pemberian BAP mampu merangsang pembentukan tunas sengon in vitro pada konsentrasi 1 ppm BAP/l. Peningkatan konsentrasi BAP akan menurunkan induksi tunas. Sementara itu, perlakuan NAA pada berbagai konsentrasi tidak mempengaruhi induksi tunas. Secara umum BAP lebih berpengaruh terhadap pembentukan tunas daripada NAA. Interaksi anatara BAP dan NAA berpengaruh tidak nyata terhadap jumlah tunas. Media terbaik untuk multipikasi tunas sengon secara in vitro adalah media MS dengan konsentrasi 1 ppm BAP/l media baik kombinasi dengan NAA atau tidak.
\end{abstract}

Kata Kunci : sengon, BAP, NAA, karat puru, in vitro

\section{PENDAHULUAN}

Kebutuhan akan kayu dan produk
kayu di Indonesia dan dunia terus
meningkat setiap tahunnya. Konsekuensi
tingginya permintaan tersebut
mengakibatkan eksplorasi kayu dari hutan
alam semakin tinggi. Hal ini menyebabkan
tekanan terhadap hutan alam sebagai
sumber utama pemenuhan kebutuhan
masyarakat akan semakin tinggi. Sekarang
hutan alam tidak dapat lagi memenuhi
permintaan tersebut karena tingkat

produktifitasnya lebih kecil daripada yang diinginkan. Solusi yang ditawarkan untuk mencukupi kekurangan tersebut adalah produksi kayu melalui Hutan Tanaman Industri (HTI).

Pembuatan HTI dalam skala besar sangat tergantung kepada penyediaan bibit dengan kuantitas dan kualitas yang tinggi. Akhir-akhir ini di bidang kehutanan mulai banyak bibit tanaman yang diproduksi secara in vitro dengan teknik kultur jaringan. Keuntungan teknik ini pelaksanaaannya tidak tergantung pada 
musim dan faktor lingkungan yang lain serta tidak memerlukan daerah pembibitan yang luas, disamping mutu bibit juga terjamin.

Salah satu kabupaten di Bengkulu yang banyak mengembangkan tanaman sengon adalah Kabupaten Kepahyang. Saat ini pertanaman sengon di Kepahyang banyak diserang oleh penyakit karat puru. Penyakit ini menyebabkan daun mengeriting, melengkung dan tidak normal. Penelitian Togatorop (2015) menyimpulkan bahwa intensitas serangan karat puru di Kepahyang makin besar sesuai dengan ketinggian dari permukaan laut. Sengon pada ketinggian 1000 dan 800 dpl terserang karat puru diatas $60 \%$ sedangkan pada ketinggian 300 dpl hanya $15,7 \%$.

Pohon sengon mempunyai banyak manfaat. Dari sisi lingkungan, sengon banyak digunakan untuk menghijaukan kembali lahan-lahan kritis, lahan di pinggir jalan atau daerah wisata yang masih terbuka. Kemampuan sengon untuk bersimbiosis dengan bakteri rhizobium, dapat mempercepat menambah bahan organik tanah melalui produksi seresah sengon yang termasuk cepat. Oleh karena itu produksi bibit sengon unggul akan menjadi penting pada masa mendatang, tidak hanya untuk tujuan produksi kayu tapi juga pengelolaan lingkungan secara umum.

Teknik perbanyakan vegetatif yang bisa dilakukan adalah perbanyakan in vitro. Sebagai tahap awal adalah penelitian perbanyakan tunas sengon. Penelitian ini akan menjadi pijakan untuk proses perbanyakan sengon secara keseluruhan. Lebih lanjut, bisa menjadi dasar untuk pengembangan vegetatif sengon unggul dan perakitan varitas baru sengon yang mempunyai karakteristik khusus misalnya varietas sengon dengan sifat unggul yaitu bebas karat tumor (karat puru). Tujuan penelitian ini adalah mengetahui pengaruh pemberian hormon Benzyl Amino Purine BAP) dan Naphtalene Acetic Acid (NAA) terhadap pertumbuhan eksplan yang berasal dari tunas sengon dan mengetahui konsentrasi BAP dan NAA yang paling tepat untuk memacu pertumbuhan eksplan sengon.

\section{METODE PENELITIAN}

Penelitian ini dilaksanakan selama 3 (tiga) bulan pada bulan Maret-Mei 2018. Penelitian dilakukan di laboratoirum Kultur Jaringan Jurusan Kehutanan Fakultas Pertanian Universitas Bengkulu. Alat yang digunakan dalam penelitian ini Laminar air flow, gelas ukur, gelas kimia, botol kultur, pipet, $\mathrm{pH}$ meter, timbangan analitik, magnetic stirer, autoclave /kukusan, scapel, alat tulis. Bahan yang digunakan dalam penelitian adalah bahan kimia untuk media MS dan bahan eksplan penelitian berupa biji sengon terpilih. Biji dipanen dari pohon induk di lingkungan Kampus Universitas Bengkulu dengan kriteria secara visual bebas dari penyakit karat puru, sehat dan merupakan pohon terbesar di populasinya.

Rancangan penelitian yang digunakan adalah Rancangan Acak Lengkap Faktorial dengan dua perlakuan yaitu pemberian hormon benzyl amino purine (BAP) dan naphatalene acetic acid (NAA). Data hasil penelitian dilakukan analisis varian dengan program SPSS dan uji lanjut menggunakan Duncan Multiple Range Test (DMRT) pada taraf $5 \%$ dan $1 \%$.

Eksplan biji sengon disterilisasi dengan bakterisida Agrept 2 gr/l larutan selama 20 menit dan dibilas dengan akuades steril 5 kali. Biji selanjuttnya direndam fungisida Dhitane M $452 \mathrm{~g} / \mathrm{l}$ larutan kemudian dibilas lagi 5 kali. Tahap berikutnya biji direndam dengan larutan Plant Preservative Medium (PPM) dengan konsentrasi $2 \mathrm{ml} / \mathrm{l}$ larutan selama 2 jam. Selanjutnya biji dikecambahkan pada media MS0. Setelah 10 hari benih akan berkecambah bagian pucuk dipotong dan kemudian ditanam dalam botol kultur berisi media MS dengan perlakuan yang telah disiapkan. 
Penelitian induksi tunas sengon menggunakan media MS dengan hormon BAP dengan dosis 0,1 , 2, dan 3 ppm. Dosis NAA sebesar $0,0.25$, dan $0,5 \mathrm{ppm}$. Total ada 4 × $3=12$ kombinasi perlakuan dengan 5 ulangan. Setiap ulangan terdiri atas 1 eksplan. Total sampel eksplan 4 x 3 x $5=60$ unit penelitian.

Peubah yang diukur dalam penelitian ini adalah persentase tumbuh eksplan dan jumlah tunas yang terbentuk per eksplan. Peubah tambahan jika ada seperti eksplan yang berkalus dan warna kalus. Pengukuran dilakukan setiap dua minggu selama tiga bulan.

\section{HASIL DAN PEMBAHASAN}

\section{Persentase Hidup Eksplan}

Pada akhir penelitian didapat bahwa persentase hidup eksplan adalah $100 \%$. Tidak ada dijumpai kontaminasi baik kontaminasi jamur maupun bakteri. Keberhasilan ini dipengaruhi oleh tingkat kesterilan saat sterilisasi eksplan dan inisiasi awal. Dengan demikian dapat disimpulkan bahwa prosedur sterilisasi eksplan yang dilakukan sudah baik. Disamping itu penambahan plant preservative mixture pada media MS sangat membantu mengurangi kontaminasi bakteri dan jamur. Syatria (2017) menyatakan bahwa pemberian $0,5-1 \mathrm{ml}$ PPM efektif untuk mensterilkan media MS dari pengaruh kontaminan meskipun proses pemasakan media tidak menggunakan autoclave dengan standar suhu $121 \mathrm{C}$ dan tekanan 2 atm. Penelitian menggunakan panci kukus biasa.

Sementara itu Plant Cell Technology Inc (2016) menjelaskan bahwa mekanisme kerja PPM adalah dengan cara penetrasi ke dalam dinding sel bakteri dan jamur sehingga dapat menghalangi aktifitas enzim-enzim kunci yang berperan dalam siklus metabolik seperti siklus citric acid dan rantai transport elektron. Plant preservative mixture juga menghalangi serapan monosakarida dan asam amino dari media kultur menuju sel bakteri dan jamur. Penambahan PPM akan dapat membunuh dan menghambat pertumbuhan kontaminan.

Beberapa penelitian yang mendukung efektifitas penambahan PPM pada media kultur seperti penelitian White dkk (2007) yang berhasil melakukan mikropropagasi dari eksplan biji yang ditanam pada media MS padat dengan penambahan $0,5 \%$ PPM untuk menghilangkan kontaminasi bakteri. Sementara itu Syatria dan Saprinurdin (2015) meneliti induksi tunas Kayu Bawang (Protium Javanicum Burm F) berhasil pada media MS dengan perlakuan konsentrasi BAP yang ditambah dengan PPM $0.5 \mathrm{ml} / \mathrm{l}$ media.

\section{Jumlah Tunas}

Hasil analisis of varian (ANOVA) untuk peubah jumlah tunas sengon dapat dilihat pada Tabel 1.

Tabel 1. Ringkasan hasil analisis varian pada taraf 5\% dan $1 \%$

\begin{tabular}{lccccc}
\hline \multirow{2}{*}{ Perlakuan } & \multicolumn{5}{c}{ Pengukuran ke- (MST) } \\
\cline { 2 - 6 } & 4 & 6 & 8 & 10 & 12 \\
\hline BAP & $* *$ & $* *$ & $* *$ & $* *$ & $* *$ \\
NAA & $\mathrm{ns}$ & $\mathrm{ns}$ & $\mathrm{ns}$ & $\mathrm{ns}$ & $\mathrm{ns}$ \\
B x N & $\mathrm{ns}$ & $\mathrm{ns}$ & $\mathrm{ns}$ & $\mathrm{ns}$ & $\mathrm{ns}$ \\
\hline
\end{tabular}

Hasil Anava pada Tabel 1 menunjukkan bawah perlakuan BAP berpengaruh sangat nyata terhadap pertambahan jumlah tunas sengon in vitro baik pada uji DMRT taraf
$5 \%$ maupun $1 \%$. Perlakuan NAA berpengaruh tidak nyata terhadap pertambahan jumlah tunas. Sementara itu 
P-ISSN: 2302- 6715

E- ISSN: 2654-7732

interaksi BAP dan NAA menunjukkan pengaruh tidak nyata.

Berdasarkan hasil analisis varian bahwa secara umum perlakuan tunggal BAP $1 \mathrm{ppm} / \mathrm{l}$ (B1) media berbeda nyata dengan B0, B2 dan B3 terhadap pertambahan jumlah tunas. Perlakuan NAA berbeda tidak nyata pada konsentrasi N0, N1, N2 terhadap pertambahan jumlah tunas. Hasil uji DMRT pengukuran ke 4, 5 dan 6 pada taraf $5 \%$ dan $1 \%$ disajikan pada Tabel 2.

Tabel 2. Uji lanjut DMRT pada taraf 5\% dan $1 \%$ untuk peubah jumlah tunas

\begin{tabular}{|c|c|c|c|c|}
\hline \multirow{3}{*}{ Rank } & \multirow{3}{*}{ Perlakuan } & \multicolumn{3}{|c|}{ Uji lanjut DMRT 1\% } \\
\hline & & 4 & 5 & 6 \\
\hline & & \multicolumn{3}{|c|}{ Non-significance ranges } \\
\hline 1 & B1 & $\mathrm{a}$ & $\mathrm{a}$ & $\mathrm{a}$ \\
\hline 2 & B2 & $\mathrm{b}$ & $\mathrm{b}$ & $\mathrm{a}$ \\
\hline 3 & B3 & bc & bc & $\mathrm{bc}$ \\
\hline 4 & B0 & $\mathrm{c}$ & $\mathrm{c}$ & $\mathrm{c}$ \\
\hline
\end{tabular}

Pertambahan jumlah tunas setiap kombinasi perlakuan selama penelitian dapat dilihat pada Gambar 1.

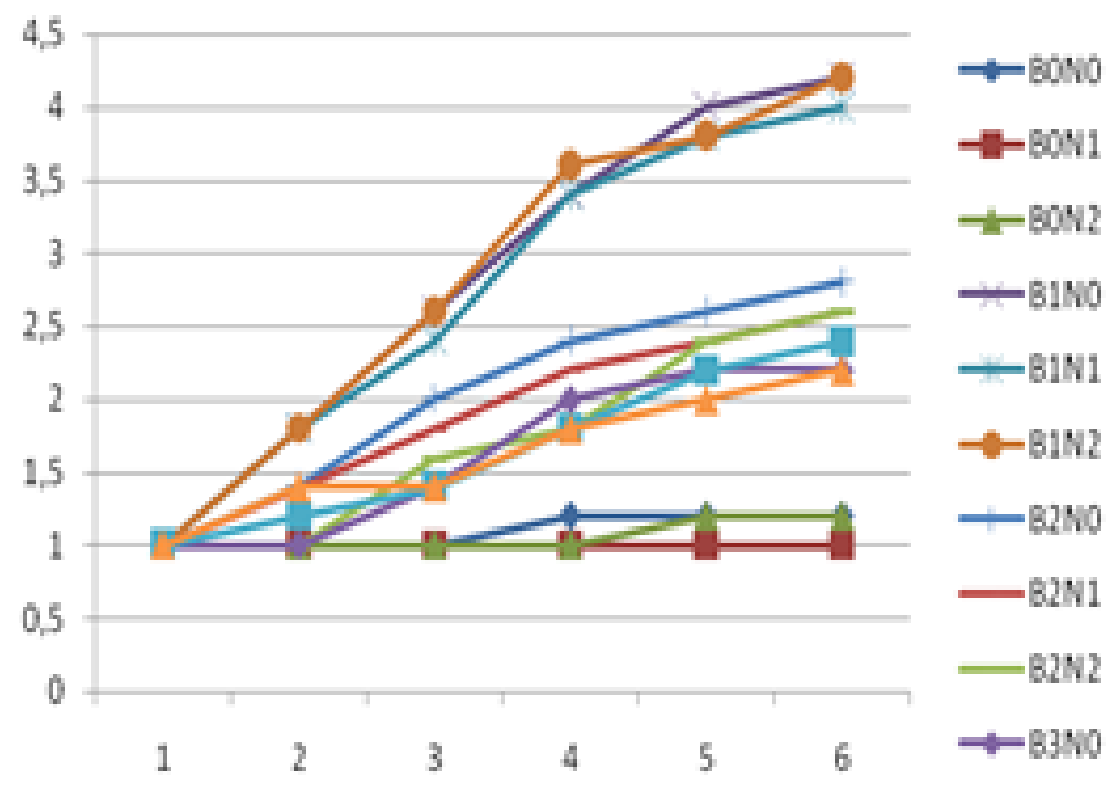

Gambar. 1 Grafik pertambahan jumlah tunas pada setiap kombinasi perlakuan

Gambar 1 menunjukkan bahwa ada kecenderungan peningkatan jumlah tunas dengan penambahan BAP. Pemberian BAP $1 \mathrm{ppm} / \mathrm{l}$ media MS memberikan rerata jumlah tunas yang terbaik dengan kombinasi perlakuan B1N0 dan B1N2 yaitu sebanyak 4,2 tunas, sedangkan perlakuan tanpa pemberian BAP atau B0 hanya menghasilkan 1,2 tunas pada kombinasi B0N0 dan B0N2. Pemberian 1 ppm BAP/l media mampu mendorong pembelahan dan perpanjangan sel sehingga memacu morfogenesis dan pembentukan tunas. Hal ini sejalan dengan pendapat Santoso dan Nursandi (2003) yang menjelaskan peranan sitokinin diantaranya adalah memacu pembentangan sel, pembesaran dan pembelahan sel. Wattimena (1988) juga menjelaskan bahwa sitokinin berperan pada berbagai aspek 
pertumbuhan dan perkembangan tanaman, seperti mendorong pembesaran sel, perpanjangan koleoptil atau batang merupakan hasil dari pembesaran tersebut. Naphtalene acetic acid biasanya digunakan untuk merangsang pembentukan kalus pada eksplan. Kombinasi NAA dan BAP pada konsentrasi BAP 1 ppm/l media tampak paling optimal untuk memacu pertambahan jumlah tunas.

Pengaruh perlakuan tunggal BAP terhadap pertambahan jumlah tunas sengon bisa dilihat pada Gambar 2. Perlakuan B1 (1 ppm BAP) menghasilkan rerata jumlah tunas terbaik sebesar 4,13 tunas.

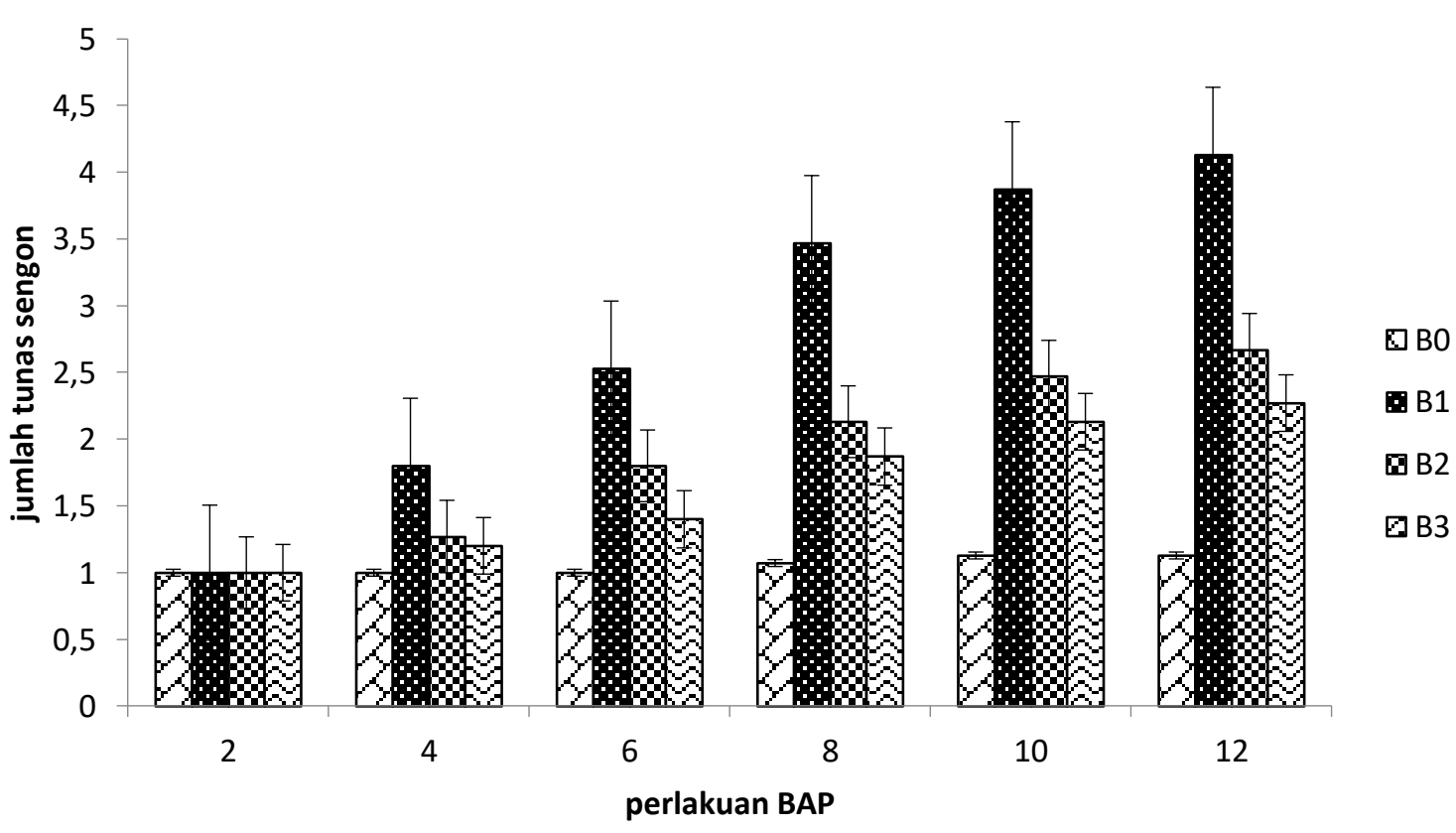

Gambar 2 Pengaruh BAP terhadap pertambahan jumlah tunas sengon

Peningkatan konsentrasi BAP pada Gambar 2 dalam media dapat mengurangi jumlah tunas yang terbentuk. Penambahan BAP menjadi 2-3 ppm BAP/l media MS cenderung lebih sedikit menghasilkan jumlah tunas dibandingkan pemberian 1 ppm BAP/l media MS. Hal ini dijelaskan oleh Wudianto (2004) bahwa hormon hanya efektif pada jumlah tertentu. Konsentrasi yang terlalu tinggi dapat merusak bagian yang terluka. Bentuk kerusakannya berupa pembelahan sel dan kalus yang berlebihan dan mencegah tumbuhnya tunas dan akar. Sedangkan konsentrasi dibawah optimum menjadi tidak efektif.

Hasil yang berbeda didapatkan pada penelitian Herawan dan Ismail (2009) bahwa pemberian $3 \mathrm{ppm}$ BAP/l media memberikan respon yang paling baik terhadap pembentukan jumlah tunas sengon. Hal ini diduga karena perbedaan jenis eksplan yang digunakan. Pada penelitian ini digunakan eksplan dari potongan pucuk kecambah sengon sedangkan pada penelitian Herawan dan Ismail (2009) menggunakan potongan kotiledon biji sengon. Dijelaskan oleh Wattimena (1988) bahwa penentuan konsentrasi zat pengatur tumbuh disesuaikan dengan tipe organ atau eksplan, metode kultur jaringan dan tujuan kultur jaringan untuk meninduksi tunas, akar, kalus dan lain-lain. Jadi kemungkinan bahwa kultur dari pucuk dan kotiledon sengon memerlukan konsentrasi 
BAP yang berbeda. Hal ini terkait dengan banyaknya sitokinin endogen yang ada pada pucuk kemungkinan lebih besar daripada sitokinin endogen pada kotiledon, sehingga kultur pucuk hanya memerlukan sitokinin eksogen lebih sedikit. Konsentrasi hormon juga berbeda untuk jenis tanaman yang berbeda. Misalnya pada penelitian Sari dkk (2009) mendapatkan bahwa pemberian 3 ppm BAP/l media merupakan perlakuan terbaik untuk menginduksi tunas pada meranti merah (Shorea seminis).

Gambar 2. dan 3 memperlihatkan bahwa penambahan jumlah tunas cenderung meningkat pada umur eksplan 6, 8, 10 MST. Pada umur 12 MST pertambahan jumlah tunas mulai menurun. Hal ini diduga bahwa pada pengukuran 3 , 4 dan 5 jumlah hormon yang ada dalam media masih mencukupi untuk kebutuhan eksplan. Namun menjelang akhir penelitan yaitu pada umur eksplan 12 MST (umur eksplan 3 bulan) ketersediaan hormon dan nutrisi sudah berkurang. Hal ini berdampak pada penurunan jumlah tunas baru yang terbentuk. Berdasarkan pengalaman, eksplan usia 3 bulan memang sudah saatnya untuk memasuki tahap subkultur berulang dengan dipindahakan ke media baru dengan hormon yang sama atau memasuki periode pengakaran dengan dipindahkan ke media baru dengan penambahan hormon perangsang akar seperti IAA dan IBA.

Sementara itu pengaruh perlakuan tunggal NAA terhadap pertambahan jumlah tunas berpengaruh tidak nayata. Hasil uji lanjut DMRT menunjukkan bahwa antar konsentrasi NAA tidak berbeda nyata dalam menginduksi jumlah tunas sengon.

\section{Kalus}

Pada penelitian dijumpai adanya pembentukan kalus pada semua perlakuan. Secara umum kalus mulai dijumpai pada pengamatan ke 4 MST (umur eksplan 1 bulan). Kalus merupakan sel tanaman yang belum terdiferensiasi dan belum mempunyai fungsi khusus. Pemberian auksin dan sitokinin dalam konsentrasi tertentu dapat mendorong morfogenesis sel kalus. Kalus bisa berkembang menjadi tunas atau akar tergantung pada keseimbangan auksin dan sitokinin yang diberikan. Kalus yang terbentuk pada penelitian ini berwarna putih, putih kekuningan dan kehijauan. Kalus warna putih (gambar 3) biasanya tidak embriogenik. Sementara itu kalus yang berwarna putih kuning kehijauan berpeluang untuk mengalami morfogenesis membentuk tunas. Gunawan (1992) menyatakan bahwa produksi kalus biasanya terbentuk dalam media yang mengandung auksin dan kadang-kadang sitokinin. Dalam penelitian ini digunakan sitokinin BAP dan auksin NAA.

Yelnititis (2013) melakukan induksi embrio somatik Shorea pinanga pada berbagai kondisi fisik media berbeda. Hasil peneltiannya menunjukkan bahwa kalus yang baik berwarna putih kekuningan dan remah (friabel). Kalus remah mmepunyai kandungan air yang lebih banyak daripada kalus kompak. Kalus remah bisa berkembang menjadi kalus embriogenik melalui pemindahan berulang atau subkultur dengan jenis media yang sama. 


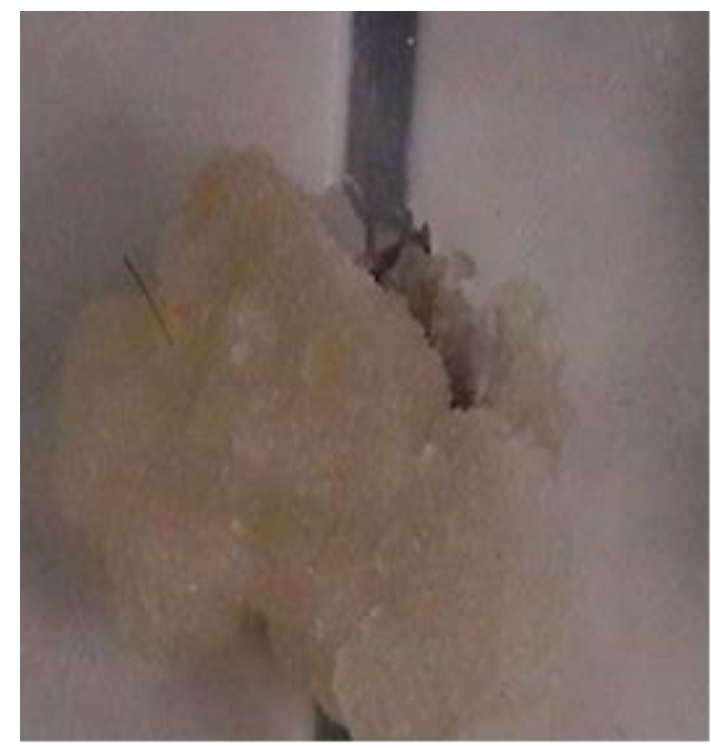

Gambar 3. Kalus berwarna putih pada perlakuan B0N0

\section{Pengembangan Sengon Bebas Karat} Puru

Penelitian mengambil bahan sumber eksplan dari pohon induk sengon di kampus Universitas Bengkulu. Pemilihan pohon induk berdasarkan pengamatan visual bahwa pohon bebas dari serangan karat puru. Pengamatan langsung tidak mendapati adanya serangan karat puru yang terlihat pada batang, ranting atau daun. Pada kasus dimana suatu daerah sudah terkena wabah penyakit karat puru tindakan yang bisa dilakukan adalah eradikasi dengan membinasakan semua tanaman yang terkena serangan dengan cara dibakar. Pertanaman selanjutnya menggunakan bibit yang diproduksi bebas karat puru misalnya yang dihasilkan dari kultur jaringan. Hasil penelitian ini akan menjadi landasan untuk pengembangan sengon tahan kuru dalam jangka panjang. Penelitian di lapangan perlu dilakukan untuk eksplorasi sengon tahan karat puru. Seleksi lapangan dengan mencari pohon unggul bisa dilakukan di pertanaman sengon yang terserang karat puru dalam skala parah. Tanaman yang bisa bertahan atau bebas dari karat puru bisa dikembangkan secara klonal melalui kultur jaringan untuk produksi massal varietas sengon karat puru. Penelitian Togotorop (2015) mengenai serangan karat puru di Kabupaten Kepahyang Propinsi Bengkulu mendapatkan data bahwa sekitar $60 \%$ pertanaman sengon terkena serangan karat puru. Berarti ada populasi ada sekitar $40 \%$ yang bisa dijadikan bahan seleksi untuk pengembangan sengon tahan karat puru. Dari populasi $40 \%$ tadi bisa diseleksi lagi mana pohon yang benar-benar bebas serangan karat puru, disamping juga memperhatikan kriteria pohon unggul secara umum seperti pohon terbesar dan tinggi di populasi tersebut. Dengan demikian hasil akhirnya akan didapatkan varietas yang bisa dikembangkan secara massal.

Pertanaman sengon di Kabupaten Kepahyang Provinsi Bengkulu kemungkinan awalnya mengintroduksi biji sengon dari wilayah yang sudah terkena wabah karat puru. Biji yang dikembangkan di Kepahyang sudah membawa spora jamur yang akhirnya berkembang disana. Spora jamur penyebab karat puru bisa 
menempel pada biji pada saat pemanenan buah. Produksi bibit sengon melalui biji beresiko tinggi ikut menyebarkan penyakit karat puru ke daerah baru yang mengintroduksi sengon dari daerah yang sudah terkena wabah karat puru. Rahayu (1988) mengatakan bahwa karat puru bisa menyerang mulai dari tingkat persemaian sampai pada pohon dewasa.

Gambar 4 menunjukkan contoh sengon yang terserang penyakit karat puru di Kabupaten Kepahyang (Togatorop,
2015). Pada tahun 2015, serangan karat puru di kabupaten Kepahyang sudah termasuk parah untuk pertanaman pada ketinggian $800 \mathrm{~m}$ dpl atau lebih. Lebih lanjut Togatorop (2015) menyarankan agar penanaman sengon sebaiknya pada ketinggian dibawah $300 \mathrm{mpl}$ dan perlu adanya pengembangan bibit yang bebas atau tahan karat puru untuk pengembangan sengon pada daerah dengan ketinggian di atas $800 \mathrm{~m} \mathrm{dpl}$.

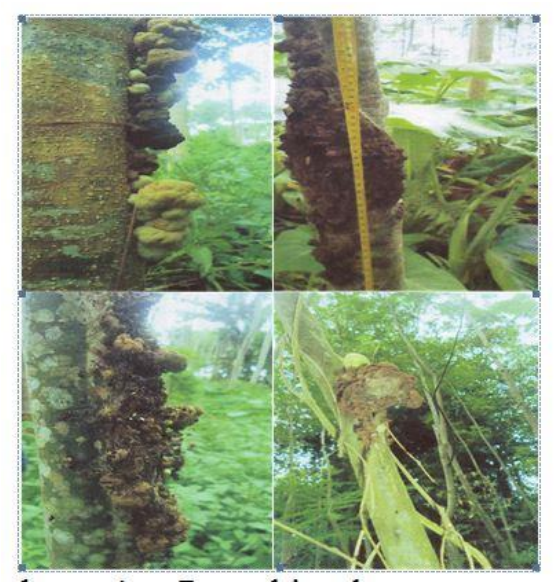

Gambar 4. Penyakit karat puru di Kepahyang (Togatorop, 2015)

Pengamatan langsung di lereng Gunung Merapi menunjukan serangan karat puru yang sangat parah. Dari tiga plot pengamatan ukuran $10 \times 10 \mathrm{~m}$ yang dibuat, hasilnya menunjukkan bahwa serangan karat puru mencapai $100 \%$. Artinya dari tiga plot yang dibuat belum dijumpai individu pohon sengon yang tahan serangan. Dari sisi eksplorasi, sebenarnya pada tingkat serangan $100 \%$ ini seleksi akan lebih efektif dilakukan. Jika pengamatan diperluas cakupannya maka kemungkinan akan ada beberapa individu yang bebas dari serangan karat puru. Individu-individu inilah yang diduga memiliki gen ketahanan terhadap karat puru. Jika seleksi dilakukan di pertanaman sengon dengan intensitas serangan $60 \%$ belum tentu menjamin bahwa yang $40 \%$ sebenarnya memiliki ketahanan terhadap karat puru. Bisa saja individu belum terkena serangan dan suatu saat akan terkena serangan penyakit juga. Namun individu dalam populasi $40 \%$ tersebut bisa menjadi titik tolak bahan penelitian.

\section{KESIMPULAN}

Berdasarkan hasil penelitian yang diperoleh dan pembahasan hasil maka dapat ditarik kesimpulan: 1). Perlakuan pemberian hormon BAP mampu merangsang pembentukan tunas sengon in vitro konsentrasi $1 \mathrm{ppm}$ BAP/lt. Peningkatan konsentrasi BAP akan menurunkan induksi tunas. Sementara itu, perlakuan NAA pada berbagai konsentrasi tidak mempengaruhi induksi tunas, 2). Media terbaik untuk multipikasi tunas sengon secara in vitro adalah media MS dengan konsentrasi $1 \mathrm{ppm} \mathrm{BAP} / \mathrm{l}$ media baik kombinasi dengan NAA atau tidak, dengan menghasilkan rerata tunas terbanyak 4,2 tunas/eksplan. 


\section{DAFTAR PUSTAKA}

Budiman, B, dan I.P. Rianti, 2014. Teknik pengendalian Penyakit Karat Puru Pada pohon Sengon. http://bp2sdmk. dephut. go.id/ emagazine/ index.php/teknis/25teknikpengendalianpenyakit-karatpuru-pada-pohon-sengon. html,. Diunduh 20 januari 2016

Departemen Kehutanan, 1999. Panduan Kehutanan Indonesia. Jakarta

Herawan, T dan B. Ismail. 2009. Penggunaan Kombinasi Auksin dan Sitokinin Untuk Menginduksi Tunas Pada Kultur Jaringan Sengon (Falcataria moluccana) Menggunakan bagian Kotiledon. Jurnal Pemuliaan Tanaman Hutan. Vol 3 No 1 Juli 2009, 23-31.

Khaerudin, 1994. Pembibitan Tanaman HTI. Penebar Swadaya. Jakarta

Plant Cell Technology Inc, 2016. Introduction about PPM. http://www.plantcelltechnology.co m/about-ppm/. Diunduh 15 Oktober 2016.

Pusat Litbang Hutan Tanaman. 2009. Penyakit Karat Puru Pada Sengon (Paraserianthes falcataria) dan Teknik Pengendaliannya. Bogor.

Prosea, 1994. Plant Resources of South East Asia (1) Timber Trees: Commercial Timbers. Bogor Indonesia.

Rahayu, 1998. Penyakit Tanaman Hutan di Indonesia. Kanisius. Yogyakarta.

Syatria, N dan Saprinurdin, 2015. Induksi tunas kayu bawang (Protium Javanicum Burm F) pada berbagai konsentrasi Benzyl Amino Purinesecara in vitro. Laporan Penelitian Universitas Bengkulu. 2014
Syatria, N (2017). Penggunaan Plant Preservative Mixture(PPM) untuk Sterilisasi Eksplan dan Media Pada Kultur In Vitro. Prosiding Seminar Nasional Bioteknologi IV Universitas Gadjah Mada. Program Studi S2/S3 Sekolah Pascasarjana UGM. Hal 257-272.

Santoso, U, dan F. Nursandi, 2003. Kultur Jaringan Tanaman. Universitas Muhammadiyah Malang.

Sari, Y.P, D.Susanto dan F. Irawan (2009) Respon Pertumbuhan Tunas Meranti Merah (Shorea seminis) dengan Pemberian Zat Pengatur Tumbuh BA (Benzil Adenin) Secara In Vitro. Jurnal Bioprospek Volume 6 N0. II September 2009.

Togatorop, H. 2015. Intensitas Serangan Penyakit Karat Puru Pada Tanaman Sengon Pada ketinggian yang Berbeda di Kepahyang Provinsi Bengkulu. Skripsi Program Studi Kehutanan Jurusan Kehutanan Fakultas Pertanian Universitas Bengkulu.

Wattimena, I.G. 2004. Penerapan Kultur Jaringan Dalam Mengatasi Kelangkaan Bibit. Pelatihan Peningkatan SDM Perguruan Tinggi Dalam Pengembangan Sistim Pertanian Berkelanjutan. Universitas Andalas. Sumatra Barat.

White, I, L.Oshima dan N.D. Leswara (2007). Antimicrobial Activity and micropropagation of Peperomia tetraphylla. Journal medical and Biological Sciences. Volume 1, Issue 1.

Yelnititis, 2013. Induksi Embrio Somatik Shorea pinanga Scheff pada Kondisi Fisik Media Berbeda. Jurnal Pemuliaan tanaman Hutan vol 7 No 2 September 2013, hal 73-84. 